\title{
Panta Rhei: an evolving scientific decade with a focus on water systems
}

\author{
ALBERTO MONTANARI, SERENA CEOLA \& EMANUELE BARATTI \\ Department of Civil, Chemical, Environmental and Materials Engineering, University of Bologna, Via del Risorgimento 2, \\ I-40136 Bologna, Italy \\ alberto.montanari@unibo.it
}

\begin{abstract}
The paper presents an overview of the activity of Panta Rhei, the research decade launched in 2013 by the International Association of Hydrological Sciences. After one year of activity Panta Rhei has already stimulated several initiatives and a worldwide involvement of researchers in hydrology and sister disciplines. Providing an overview of the status of Panta Rhei is essential to further promote the participation of scientists and the completion of its structure, which is currently being shaped by receiving Research Theme and Working Group proposals from the community.
\end{abstract}

Key words Panta Rhei; hydrology; society; change

\section{INTRODUCTION}

Panta Rhei, the new scientific initiative of the International Association of Hydrological Sciences (IAHS) for the decade 2013-2022, was launched in Gothenburg, Sweden, in July 2013, during the IAHS General Assembly (Montanari et al. 2013). Since then, the governance of Panta Rhei has been defined by nominating the Target Leaders, and a scientific session at the Fall Meeting of the American Geophysical Union officially started the scientific activity.

Panta Rhei is a grassroots, bottom-up research endeavour and therefore IAHS decided to stimulate the scientific community to take the lead in defining its structure. An open call for the definition of Research Themes (RTs), to address the Panta Rhei Science Questions, and for the creation of the first Working Groups (WGs) was issued in November 2013. Open and bottom-up research initiatives are exciting opportunities for researchers, but effective involvement of the community is needed to make them fully operational and inclusive. Panta Rhei met this challenge as the first call for RTs and WGs was a success. A total of $22 \mathrm{WG}$ and 11 RT proposals were received by IAHS, involving nearly 250 scientists from several countries. This first and positive result is a confirmation of the popularity of IAHS and its scientific decades, which effectively promote the involvement of young scientists and stimulate educational and research initiatives in hydrology. This paper presents a preliminary summary of the activity of Panta Rhei, and also highlights its first research results.

\section{HYDROLOGY, CHANGE AND SOCIETY - A RESEARCH CHALLENGE}

The interaction among hydrological systems, change and society has been recently studied by an increasing number of contributions stimulated by several initiatives and developments, including Panta Rhei. In particular, Panta Rhei is committed to broadening the focus of hydrological change by including climate modelling, which often is the main research goal of papers dealing with change and the connections between hydrology and society (see, for instance, recent papers by AghaKouchak and Mehran 2013, Carey et al. 2013, Crosbie et al. 2013, Ficklin et al. 2013, Hagemann et al. 2013, Henley et al. 2013, Konar et al. 2013, Mengistu et al. 2013, Miller et al. 2013, Moody and Brown, 2013, Mutiibwa and Irmak, 2013, Null and Viers, 2013, Teegavarapu, 2013). A relevant stimulus to such a way forward was also the introduction of the concept of sociohydrology (Sivapalan et al. 2012, Lane 2014), which is based on the recognition that hydrology coevolves with society as a result of the human impact on hydrological dynamics. While classical hydrology traditionally focused on pristine catchments to gain deep understanding of water cycle features and relationships, socio-hydrology aims to achieve an improved comprehension of the impacts of anthropogenic development on the environment (see, for instance, Brath et al. 2002, 2006) and water systems in particular. 
Socio-hydrology was the subject of numerous recent contributions. A special issue on "Predictions under change: water, earth, and biota in the Anthropocene", edited by M. Sivapalan, T. J. Troy, V. Srinivasan, A. Kleidon, D. Gerten and A. Montanari, is being produced by Hydrology and Earth System Sciences, and already has more than 30 accepted papers. Among them, some articles explicitly recognize the contribution, in terms of ideas, of Panta Rhei (e.g. Thompson et al. 2013, Gupta et al. 2014, Savenije et al. 2014). Additional recent contributions focusing on the interaction between hydrology and society include Awange et al. (2013), Brown et al. (2013), Devineni et al. (2013), Nazemi et al. (2013), Paton et al. (2013) and Patterson et al. (2013).

Moreover, the concept of environmental change was discussed in several recent papers (see, for instance, Gebrehiwot et al. 2013, Koutsoyiannis 2013, Liu et al. 2013, Rootzén and Katz 2013, Steinschneider et al. 2013, Mejia et al. 2014). Some contributions have already presented attempts to provide socio-hydrological models (Di Baldassarre et al. 2013, Konar and Caylor 2013, O'Bannon et al. 2014, O'Connell and O'Donnell 2014, Viglione et al. 2014), that allow the derivation of meaningful projections of possible future environmental and societal developments.

Coupling the dynamics of hydrology and human development inevitably implies an increased complexity of models with involvement of a large number of parameters that are difficult to calibrate. The challenge for future research is to reach a compromise between the complexity of models and their applicability. This purpose has been explicitly recognized by Panta Rhei which elected "Science in practice" as one of its targets. Indeed, socio-hydrological models need to be developed with a pragmatic and interdisciplinary approach, by recognizing that the presence of uncertainty is unavoidable and therefore limits predicting capabilities. Increasing unknowns in models imply an increased complexity and a decreasing predictive ability (Fig. 1). However, achieving a better understanding of the functioning of hydrological processes under human impact, with the aid of new monitoring technologies and information, is planned. Gaining such improved insights is the real challenge for Panta Rhei, therefore providing a real practical benefit for planning adaptation measures to environmental change.

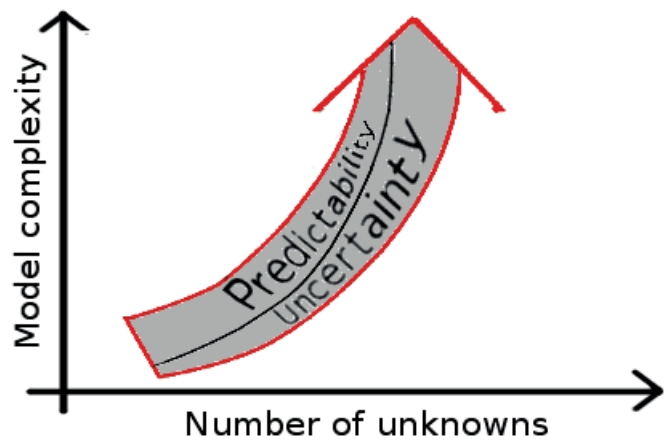

Fig. 1 Trade-off between model complexity, uncertainty and predictive capabilities.

\section{PANTA RHEI - ACTIVITIES DURING THE FIRST YEAR}

Panta Rhei was officially launched in July 2013 and the first months of work demonstrated its popularity throughout the hydrological community, clearly highlighting the effectiveness of IAHS research initiatives. Whereas, on the one hand, Panta Rhei is profiting from the success of the previous IAHS scientific decade on "Prediction in ungauged basins" (Sivapalan et al. 2003, Bloeschl et al. 2013, Hracowitz et al. 2013), on the other hand, it is clear that the worldwide consultation coordinated by IAHS to set up Panta Rhei was successful in identifying a unifying theme for the entire hydrological community (Montanari et al. 2013).

\section{Research Themes and Working Groups}

In November 2013 the Panta Rhei governance issued a call for Research Themes (RTs) and Working Groups (WGs). IAHS agreed to adopt a bottom-up philosophy to shape the structure of Panta Rhei and therefore the community was involved in the identification of the key research issues, thus 
stimulating the active participation of scientists from all over the world. The call for RTs and WGs will be permanently open during the first biennium of Panta Rhei but an interim deadline of 31 January 2014 was set for stimulating the submission of start-up proposals. To date, 11 RT (see Table 1) and $22 \mathrm{WG}$ (see Table 2) proposals have been received.

Table 1 Research Themes proposed by the community for Panta Rhei (up to March 10, 2014).

\begin{tabular}{ll}
\hline Research theme & Proposer \\
\hline Transdisciplinarity & Tobias Krueger \\
Mountain hydrology & Shreedhar Maskey \\
Large-scale water projects and society & Bellie Sivakumar \\
Physics of changes & Alexander Gelfan \\
Water footprint assessment & Saket Pande \\
Water and energy fluxes in a changing environment & Maria J. Polo \\
Epistemic uncertainties & Paul Smith \\
Hydro-meteorological extremes: Decision making in an uncertain & Adrián Pedrozo Acuña \\
environment & Jos Timmermans \\
Global change in hydrology and society & Aleksandr Tskhai \\
Reservoirs' impact & \\
\hline
\end{tabular}

Table 2 Working Groups proposed by the community for Panta Rhei (up to 10 March 2014).

\begin{tabular}{ll}
\hline Working Group & Chair \\
\hline Hydro-meteorological extremes: Decision making in an uncertain & Adrián Pedrozo Acuña \\
environment & Bellie Sivakumar \\
Large dams, society, and environment & Ana Mijic \\
Thirsty future: energy and food impacts on water & Hong \\
Changing biogeochemistry of aquatic systems in the Anthropocene & Tobias Krueger \\
Transdisciplinarity & Ronald van Nooijen \\
Natural and man-made control systems in water resources & Maria J. Polo \\
Water and energy fluxes in a changing environment & Paul Smith \\
Epistemic uncertainties & Arjen Y. Hoekstra \\
Comparative water footprint studies & Hilary McMillan \\
Hydrologic services and hazards in multiple ungauged basins & Alberto Viglione \\
Understanding flood changes & Alexander Gelfan \\
Physics of hydrological predictability & Shreedhar Maskey \\
Mountain hydrology & Vazkén Andreassian \\
Large sample hydrology & Veena Srinivasan \\
Socio-hydrologic modelling and synthesis & Tatiana Bibikova \\
Sustainable water supply in urban change & Alfonso Mejia \\
Water footprint of cities & Alfonso Mejia \\
Evolving urban water systems & Heidi Kreibich \\
Changes in flood risk & Attilio Castellarin \\
Anthropogenic and climatic controls on water availability (ACCuRAcY) & Alberto Montanari \\
Floods in historical cities & Hafzullah Aksoy \\
Prediction under change (PUC) & \\
\hline
\end{tabular}

The WG includes about 250 scientists from several different countries. Out of the entire list of WGs, five specifically focus on water systems. This is a promising picture for promoting the assessment, modelling and prediction of the status of water supply, irrigation and drainage systems in a changing environment.

As previously mentioned, the call for RTs and WGs is permanently open during the first biennium of Panta Rhei. Instructions to submit proposals are provided at www.iahs.info/pantarhei. Scientists who are interested in affiliating to Panta Rhei may also consider the option of joining existing WGs. The WGs are open and researchers are invited to refer to the related WG chair. 


\section{Scientific symposia}

A scientific session entitled "Hydrological change and water systems: feedbacks, prediction, and experimental management" was proposed under the auspices of Panta Rhei and held at the 2013 Fall Meeting of the American Geophysical Union (AGU). The session was convened by N. Basu (University of Waterloo, Canada), A. Montanari (University of Bologna, Italy), M.C. Bruno (Mach Foundation, Italy) and T. Melis (USGS, USA). Fifty-four oral and poster contributions were presented, evidence of a positive outcome. Six invited presentations were delivered by N. van de Giesen (Technical University Delft, Netherlands), C.T. Robinson (EAWAG, Switzerland), C.P. Konrad (USGS, USA), I. Creed (Western University, Canada), C. Lane (US EPA Office of Research and Development, Cincinnati, Ohio, USA), A. Viglione (Technical University Wien, Austria) and U. Lall (Columbia University, USA) on the three main themes of "Reservoir operation and control", "Peatland and wetlands" and "Socio-hydrology and change".

Three symposia dedicated to Panta Rhei were convened at the 2014 General Assembly of the European Geosciences Union (EGU). The first was a visionary session titled "Panta Rhei: a vision and an agenda for the next 10 years of hydrological research in support of society", convened by G.H. de Rooij (Helmholtz Centre for Environmental Research - UFZ, Germany) and A. Montanari (University of Bologna, Italy). This session hosted the talks of six invited speakers: H. Savenjie (Technical University Delft, Netherlands), D. Koutsoyiannis (National Technical University of Athens, Greece), U. Lall (Columbia University, USA), B. Arheimer (SMHI, Sweden), E. FoufoulaGeorgiou (Indiana University, USA) and S. Tamea (Politecnico di Torino, Italy). EGU 2014 also hosted the sessions "Stakeholders, public involvement and collaborative processes in hydrology research and water management", convened by T. Krueger (University of East Anglia, UK) and G. Carr (Technical University Wien, Austria), and "Change in climate, hydrology and society", convened by D. Koutsoyiannis (National Technical University of Athens, Greece), J. de Lima (University of Coimbra, Portugal), H. Lins (USGS, USA), X.L. Wang (Environment Canada, Canada), M. Mudelsee (Climate Risk Analysis, Germany), C. Cudennec (INRA, France) and C. Maftei (Ovidius University, Romania).

Finally, the conference "Evolving Water Resources Systems - Understanding, Predicting and Managing Water-Society Interactions", held in Bologna (Italy) during 4-6 June 2014, is organized within the framework of Panta Rhei. A community paper will be produced after the conference to provide a vision for the future of water resources systems.

\section{Promoting cooperation and visibility of scientific initiatives and publishing}

One of the main missions of Panta Rhei is to promote the visibility of hydrological research and publishing. To this end, the Panta Rhei website (www.iahs.info/pantarhei) reports in the main page any Panta Rhei initiative. Researchers are invited to use the contact page of the website if they wish to communicate any related news.

Visibility of scientific publications will be achieved by hosting on the Panta Rhei website two lists of papers that are relevant to the subject of change in hydrology and society. One list will include papers that explicitly acknowledge Panta Rhei (the website provides instructions to this end) while a second list will include papers that are relevant to the Panta Rhei activity. Papers are included in the above lists on request of the authors, who are invited to use the contact page of the website to highlight their contributions. The community is invited to refer to the above lists of papers when working on Panta Rhei; they are meant to provide a coherent information source and to support the development of future research activities.

\section{THE NEAR FUTURE OF PANTA RHEI}

The activity of Panta Rhei will move forward in the first biennium with the objective of completing the structure of the RTs and WGs, while promoting educational and scientific initiatives. The latter will include scientific session at conferences, workshops and dedicated short courses. The most challenging commitments of Panta Rhei are those related to encouraging visibility and 
interdisciplinarity. In particular, interdisciplinarity will require a dedicated effort, to not just involve scientists from sister disciplines, but rather to make the cooperation really fruitful for carrying out science in practice, as suggested by one of the targets Panta Rhei.

Community papers will be produced at the end of the first biennium to project Panta Rhei into the future. The Panta Rhei governance will be rotated each biennium: it is important that continuity is ensured in the development of the activity by means of effective involvement of the worldwide hydrological community.

Interested researchers are invited to use the contact page of www.iahs.info/pantarhei to get in contact with Panta Rhei.

Acknowledgements The present work was developed within the framework of the Panta Rhei Research Initiative of the International Association of Hydrological Sciences (IAHS).

\section{REFERENCES}

AghaKouchak, A. and Mehran, A. (2013) Extended contingency table: Performance metrics for satellite observations and climate model simulations. Water Resources Research 49, 7144-7149, doi:10.1002/wrcr.20498.

Awange, J. L., et al. (2013) Potential impacts of climate and environmental change on the stored water of Lake Victoria Basin and economic implications. Water Resources Research 49, 8160-8173, doi:10.1002/2013WR014350.

Blöschl, G., et al. (2013) Runoff Prediction in Ungauged Basins. Synthesis across Processes, Places and Scales. Cambridge University Press.

Brath, A., Castellarin, A., and Montanari, A. (2002) Assessing the effects of land-use changes on annual average gross-erosion. Hydrology and Earth System Sciences 6(2), 255-266.

Brath, A., Montanari, A., and Moretti, G. (2006) Assessing the effect on flood frequency of land use change via hydrological simulation (with uncertainty). Journal of Hydrology 324, 141-153, doi:10.1016/j.jhydrol.2005.10.001.

Brown, T. C., Foti, R., and Ramirez, J. A. (2013) Projected freshwater withdrawals in the United States under a changing climate. Water Resources Research 49, 1259-1276, doi:10.1002/wrcr.20076.

Carey, S. K., et al. (2013) Use of color maps and wavelet coherence to discern seasonal and interannual climate influences on streamflow variability in northern catchments. Water Resources Research 49, 6194-6207, doi:10.1002/wrcr.20469.

Crosbie, R. S., et al. (2013) Potential climate change effects on groundwater recharge in the High Plains Aquifer, USA, Water Resources Research 49, 3936-3951, doi:10.1002/wrcr.20292.

Devineni, N., Perveen, S., and Lall, U. (2013) Assessing chronic and climate-induced water risk through spatially distributed cumulative deficit measures: A new picture of water sustainability in India. Water Resources Research 49, 2135-2145, doi:10.1002/wrcr.20184.

Di Baldassarre, G., et al. (2013) Socio-hydrology: conceptualising human-flood interactions. Hydrology and Earth System Sciences 17, 3295-3303, doi:10.5194/hess-17-3295-2013.

Ficklin, D. L., Stewart, I. T. and Maurer, E. P. (2013) Effects of climate change on stream temperature, dissolved oxygen, and sediment concentration in the Sierra Nevada in California. Water Resources Research 49, 2765-2782, doi:10.1002/wrcr.20248.

Gebrehiwot, S. G., et al. (2013) Hydrological change detection using modeling: Half a century of runoff from four rivers in the Blue Nile Basin. Water Resources Research 49, 3842-3851, doi:10.1002/wrcr.20319.

Gupta, H. V., et al. (2014) Large-sample hydrology: a need to balance depth with breadth. Hydrology and Earth System Sciences 18, 463-477, doi:10.5194/hess-18-463-2014.

Hagemann, S., et al. (2013) Climate change impact on available water resources obtained using multiple global climate and hydrology models. Earth System Dynamics 4, 129-144, doi:10.5194/esd-4-129-2013, 2013.

Henley, B. J., Thyer, M. A. and Kuczera, G. (2013) Climate driver informed short-term drought risk evaluation. Water Resources Research 49, 2317-2326, doi:10.1002/wrcr.20222.

Hrachowitz, M., et al. (2013). A decade of Predictions in Ungauged Basins (PUB) — a review. Hydrological Sciences Journal 58 (6), 1198-1255, doi: 10.1080/02626667.2013.803183.

Konar, M. and Caylor, K. K. (2013) Virtual water trade and development in Africa. Hydrology and Earth System Sciences 17, 3969-3982, doi: 10.5194/hess-17-3969-2013.

Konar, M., et al. (2013) Virtual water trade flows and savings under climate change. Hydrology and Earth System Sciences 17 , 3219-3234, doi: 10.5194/hess-17-3219-2013.

Koutsoyiannis, D. (2013) Hydrology and change. Hydrological Sciences Journal 58(6), 1177-1197.

Lane, S. N. (2014) Acting, predicting and intervening in a socio-hydrological world. Hydrology and Earth System Sciences 18, 927-952, doi: 10.5194/hess-18-927-2014.

Liu, M., et al. (2013) Long-term trends in evapotranspiration and runoff over the drainage basins of the Gulf of Mexico during 1901-2008. Water Resources Research 49, 1988-2012, doi:10.1002/wrcr.20180.

Mejía, A., et al. (2014) A stochastic model of streamflow for urbanized basins, Water Resources Research 50, doi:10.1002/2013WR014834.

Mengistu, S. G., Quick, C. G., and Creed, I. F. (2013) Nutrient export from catchments on forested landscapes reveals complex nonstationary and stationary climate signals. Water Resources Research 49, 3863-3880, doi:10.1002/wrcr.20302.

Miller, W. P., et al. (2013) Predicting regime shifts in flow of the Gunnison River under changing climate conditions. Water Resources Research 49, 2966-2974, doi:10.1002/wrcr.20215.

Montanari, A., et al. (2013) "Panta Rhei - Everything Flows": Change in hydrology and society - The IAHS Scientific Decade 2013-2022. Hydrological Sciences Journal 58(6), 1256-1275, doi:10.1080/02626667.2013.809088. 
Moody, P. and Brown, C. (2013) Robustness indicators for evaluation under climate change: Application to the upper Great Lakes. Water Resources Research 49, 3576-3588, doi:10.1002/wrcr.20228.

Mutiibwa, D. and Irmak, S. (2013) AVHRR-NDVI-based crop coefficients for analyzing long-term trends in evapotranspiration in relation to changing climate in the U.S. High Plains. Water Resources Research 49, doi:10.1029/2012WR012591.

Nazemi, A., et al. (2013) A stochastic reconstruction framework for analysis of water resource system vulnerability to climateinduced changes in river flow regime. Water Resources Research 49, doi:10.1029/2012WR012755.

Null, S. E. and Viers, J. H. (2013) In bad waters: Water year classification in nonstationary climates. Water Resources Research 49, doi:10.1002/wrcr.20097.

O'Bannon, C., et al. (2014) Globalization of agricultural pollution due to international trade. Hydrology and Earth System Sciences 18, 503-510, doi:10.5194/hess-18-503-2014.

O'Connell, P. E. and O'Donnell, G. (2014) Towards modelling flood protection investment as a coupled human and natural system. Hydrology and Earth System Sciences 18, 155-171, doi:10.5194/hess-18-155-2014.

Paton, F. L., Maier, H. R. and Dandy, G. C. (2013) Relative magnitudes of sources of uncertainty in assessing climate change impacts on water supply security for the southern Adelaide water supply system. Water Resources Research 49, 16431667, doi:10.1002/wrcr.20153.

Patterson, L. A., Lutz, B. and Doyle, M. W. (2013) Climate and direct human contributions to changes in mean annual streamflow in the South Atlantic, USA. Water Resources Research 49, 7278-7291, doi:10.1002/2013WR014618.

Rootzén, H. and Katz, R. W. (2013) Design Life Level: Quantifying risk in a changing climate. Water Resources Research 49, 5964-5972, doi:10.1002/wrcr.20425.

Savenije, H. H. G., Hoekstra, A. Y. and Van der Zaag, P. (2014) Evolving water science in the Anthropocene. Hydrology and Earth System Sciences 18(1), 319-332, doi: 10.5194/hess-18-319-2014.

Sivapalan, M., et al. (2003) IAHS Decade on Predictions in Ungauged Basins (PUB), 2003-2012: Shaping an exciting future for the hydrological sciences, Hydrological Sciences Journal 48(6), 857-880, doi: 10.1623/hysj.48.6.857.51421.

Sivapalan, M., Savenije, H. H. G. and Blöschl, G. (2012) Socio-hydrology: a new science of people and water. Hydrological Processes 26, 1270-1276. doi: 10.1002/hyp.8426.

Steinschneider, S., Yang, Y. C. E. and Brown, C. (2013) Panel regression techniques for identifying impacts of anthropogenic landscape change on hydrologic response. Water Resources Research 49, 7874-7886, doi: 10.1002/2013WR013818.

Teegavarapu, R. S. V. (2013) Climate change-sensitive hydrologic design under uncertain future precipitation extremes. Water Resources Research 49, 7804-7814, doi: 10.1002/2013WR013490.

Thompson S. E., et al. (2013) Developing predictive insight into changing water systems: use-inspired hydrologic science for the Anthropocene. Hydrology and Earth System Sciences 17, 5013-5039. doi:10.5194/hess-17-5013-2013.

Viglione, A., et al. (2014) Insights from socio-hydrology modelling on dealing with flood risk - roles of collective memory, risktaking attitude and trust. Journal of Hydrology, http://dx.doi.org/10.1016/j.jhydrol.2014.01.018. 